\title{
Drivers and Performance Outcomes of Supplier Innovation Generation in Customer-Supplier Relationships: The Role of Power-Dependence*
}

\author{
Ruey-Jer "Bryan" Jean \\ National Chengchi University, 64, Sec.2 Zhi-Nan Road, Taipei, 11605, Taiwan, \\ e-mail: bryan@nccu.edu.tw \\ Daekwan Kim \\ Florida State University, Department of Marketing, College of Business, Tallahassee, FL \\ 32306-1110,e-mail:dkim@cob.fsu.edu \\ Rudolf R. Sinkovics ${ }^{\dagger}$ \\ The University of Manchester, Manchester Business School, Booth Street West, Manchester \\ M156PB, UK, e-mail: Rudolf.Sinkovics@manchester.ac.uk
}

\begin{abstract}
While innovations generated by supply channel relationships, as opposed to individual partners, play an increasingly important role in the success of all supply chain partners, there has been a dearth of research in the literature on how supply chain relationships cultivate the process of such innovation generation. We explore supplier market knowledge acquisition, relationship learning, systems collaboration, and technological uncertainty as antecedents of supplier innovation generation, which is in turn hypothesized to positively affect the relationship performance of the supplier. Furthermore, supplier dependence on the buyer is investigated as a moderator of the effects of such antecedents on supplier innovation generation. Empirical tests, which used a sample of 236 Taiwanese executives, supported most of the hypotheses, and some implications of the results are discussed. [Submitted: April 28, 2011. Revised: September 19, 2011; March 1, 2012; April 15, 2012. Accepted: April 20, 2012.]
\end{abstract}

Subject Areas: Dependence, Innovation, Power, Supplier, and Supply Chain.

*We are grateful to the editor Asoo J. Vakharia and the associate editor for their thoughtful support of this manuscript in the review process. We also acknowledge constructive comments from three anonymous reviewers, and feedback from members of the Comparative and International Business Research Centre (CIBER) at Manchester Business School (http://www.mbs.ac.uk/ciber) who were instrumental in developing this article toward publication.

${ }^{\dagger}$ Corresponding author. 


\section{INTRODUCTION}

Innovation is considered to be a key to firms' success in the competitive business environment. Recently, innovation outsourcing has become a megatrend and has helped many companies, such as IBM, HP, and Dell, to reduce their research and development $(R \& D)$ budgets, while relying on their external suppliers to take more responsibility for design and product development (Azadegan \& Dooley, 2010). This trend is turning suppliers into an increasingly important source of product and process innovation. However, developing effective supplier-driven innovation involves many challenges. Henke and Zhang (2010) recently showed that customers' exploitation of power in the exchange relationship with their suppliers is detrimental to supplier innovation activities. In addition, geographical or cultural separation between exchange partners increases coordination costs and business risks, creating significant obstacles to innovation generation in the supply chain relationship.

Furthermore, in terms of the outcomes of innovation generation within supply chains, it has been debated whether delegating more responsibility for innovative activities to suppliers leads to benefits for both suppliers and buyers in the supply chain relationship. On the one hand, innovation outsourcing allows companies to focus more precisely on their core competence and reduce costs. On the other hand, the outsourcing of high-value-adding activities entails risks, such as the loss of critical knowledge, and ultimately can erode a firm's internal capabilities.

While researchers have studied extensively how to manage and facilitate innovative activities and discussed the implications, the literature has focused largely on intrafirm rather than interfirm contexts. Roy, Sivakumar, and Wilkinson (2004, p. 61) note that there is a "dearth of research" on innovation generation in buyer-seller relationships. It can be argued that the conditions that facilitate innovation in intra- and interorganizational contexts may differ. For example, the literature suggests that because of the physical and psychological distance between exchange parties, knowledge-sharing routines might be more important for stimulating innovation generation in supply chains (Cheung, Myers, \& Mentzer, 2010).

Further, power plays a central role in business-to-business exchange relationships (Zhao, Huo, Flynn, \& Yeung, 2008). In an exchange relationship characterized by significant power asymmetry, the less dependent party can exert power to exploit the other. While the literature suggests that power-dependence may affect firms' innovative activities, empirical evidence on the issue is sparse, with the exceptions providing mixed results. For example, Yli-Renko and Janakiraman (2008) find that dependence is detrimental to supplier innovation. However, Wang, Bradford, $\mathrm{Xu}$, and Weitz (2008) find no significant relationship between power and creativity in interfirm relationships. Accordingly, the relationship between power-dependence and innovation in channel relationships needs further empirical investigation. Finally, another deficiency in the literature is that most studies concentrate on the benefits to customers of suppliers' innovative activities within supply chain relationships (e.g., Hult, Hurley, Giunipero, \& Nichols, 2000; Azadegan \& Dooley, 2010). Very little is known about the performance implications for suppliers. 
This study contributes to the existing knowledge in three ways. First, while prior research has focused on the drivers of innovation activities in individual firms, we investigate the drivers of innovation generation in customer-supplier relationships. Drawing on the knowledge-based view (KBV) (Grant, 1996a, 1996b), we identify three firm aspects that influence the process of innovation generation: specifically, organizational (the generation of supplier market information and relationship learning), technological (systems collaboration), and environmental (technological uncertainty) factors that affect innovation in customer-supplier exchange relationships. Second, we empirically examine innovation generation and how it is linked to supplier-customer relationship performance-an important, but still equivocal issue. Third, we explore the moderating effects of supplier dependence on the relationships between the drivers of innovation generation and its customer-supplier relationship performance outcomes. For this, we integrate resource dependence theory (RDT) (Pfeffer \& Salancik, 1978) with network theory (Rowley, 1997).

The empirical setting of this article consists of cross-border customersupplier relationships between Taiwanese contract manufacturers (suppliers) and their international original equipment manufacturer (OEM) customers in the electronics industry. International OEM customer-supplier relationships in the Taiwanese electronics industry offer an excellent setting for this study for the following reasons: (i) Taiwanese suppliers strongly depend on their international OEM customers and exhibit significant power asymmetry in their exchange relationships (Jean, Sinkovics, \& Cavusgil, 2010a); (ii) Taiwanese suppliers have recently taken on more responsibility for product innovation for their international OEM customers and have transitioned from the role of OEMs to that of original design manufacturers. New product development is a critical and particularly challenging task for these types of firms because they operate with limited resources and organizational capabilities. Taiwanese suppliers have been striving to enhance their innovative capabilities by providing better products and services to their international OEM customers, in order to increase their bargaining power.

\section{CONCEPTUAL FRAMEWORK AND HYPOTHESES}

Relying on the definition of Nielsen and Lielsen (2009), innovation in this study consists of product and process innovation, generated through customer-supplier relationships. According to the relationship view (Dyer \& Singh, 1998) and organizational learning theory (Hult et al., 2000), the customer-supplier relationship, or the interfirm relationship in general, is the locus of innovation through effective learning (Powell, Koput, \& Smith-Doerr, 1996). Hence, innovation in customersupplier relationships refers to the application (or utilization) of external knowledge to generate new products or processes in exchange relationships. This is consistent with the KBV, which highlights the importance of knowledge integration and application in innovation generation (Grant, 1996a, 1996b). However, we focus primarily on the supply side of innovation, rather than the demand-side issue of the diffusion of innovation among organizations (or innovation adoption). The rationale is that the literature to date has focused largely on innovation adoption, but there is currently a tremendous shift in focus taking place, from the adoption of 
innovation toward understanding the drivers and outcomes of innovation generation (Vincent, Bharadwaj, \& Challagalla, 2004). Product and process-related innovative activities contribute to the overall innovation so that continual improvements in manufacturing processes help firms not only to maintain product-innovation-based competitiveness, such as product quality enhancement and new product development, but also to improve their future innovation capabilities. To this end, in our research we differentiate between innovation and organizational innovativeness, because innovation is typically an outcome-oriented measure, as in "new product and process innovation," while innovativeness captures the firm-level orientation toward, and culture of, innovation (Provan \& Gassenheimer, 1994; Hurley \& Hult, 1998).

We draw on the KBV and identify technological, organizational, and environmental factors as antecedents of innovation in customer-supplier relationships. According to the KBV, innovation is the output of knowledge acquisition, sharing, and accessing, within and between organizations (Grant, 1996b; Grant \& Baden-Fuller, 2004). The literature suggests that product and service innovation require different types of knowledge, including knowledge of markets and technology (Sullivan \& Marvel, 2011). In addition, the KBV argues that innovation generation in the supply chain context includes the processes of knowledge exploration and exploitation. First, knowledge exploration and generation require supply chains as vehicles of learning, in which each member firm uses the supply chain to transfer and absorb their partners' knowledge bases. Second, knowledge exploitation and application point to a form of knowledge sharing in which each member firm accesses its partners' stocks of knowledge in order to exploit complementarities, but with the intention of maintaining their own distinctive bases of specialized knowledge (Grant \& Baden-Fuller, 2004). Accordingly, the conceptual model of the study, as shown in Figure S2, postulates that innovation generation in customer-supplier relationships is enhanced by supplier market knowledge acquisition, relationship learning, systems collaboration, and technological uncertainty, as the KBV suggests. The research model incorporates different contexts of knowledge exploration and exploitation, including market knowledge acquisition, knowledge accessing processes (relationship learning), virtual and IT-enabled learning (systems collaboration), and technological knowledge-intensive environments (technological uncertainty) (Brockman \& Morgan, 2003; Nielsen \& Nielsen, 2009).

The literature argues that market knowledge acquisition, in terms of both customer and competitor information, is an external knowledge integration mechanism. According to Zhou and Li (2012), market knowledge acquisition represents an external knowledge integration mechanism that can help capture, interpret, and deploy a firm's knowledge base. In addition, market knowledge acquisition facilitates the absorption of critical knowledge from external market sources, including customers and competitors. Hence, the concept of market knowledge integration as a knowledge integration mechanism enhances firms' absorptive capacity related to the identification of knowledge from the environment through explorative learning (Cohen \& Levinthal, 1990). In addition, we add an interorganizational context through the use of relationship learning (Jean, Sinkovics, \& Kim, 2008; Jean \& Sinkovics, 2010). This refers to a joint activity between a supplier and a 
customer in which the two parties share market information. Such information is then jointly interpreted and integrated into a shared relationship-domain-specific memory that changes the range or likelihood of relationship behavior (Selnes \& Sallis, 2003). Because of this, such information sharing is considered a crucial collective learning process through which firms can access other members' market knowledge and drive innovations in customer-supplier relationships.

Regarding interorganizational learning, the literature also maintains that organizational absorptive capacity plays a role in efficient learning (Grant, 1996b; Malhotra, Gosain, \& Sawy, 2005). Absorptive capacity refers to an organization's ability to add new knowledge to existing knowledge (Grant, 1996b, p. 111) and such a capacity involves a set of organizational routines and processes that organizations use to acquire, assimilate, transform, and exploit knowledge to produce organizational capabilities (Malhotra et al., 2005). For Grant (1996b), absorptive capacity is one of the important organizational characteristics that help transform knowledge into value in the process of knowledge management. Reflecting this, we integrate absorptive capacity into our framework implicitly. Specifically, we expect relationship learning to affect the level of organizational innovation to the extent that both the supplier and the customer have absorptive capacity. In other words, relationship learning is conceptualized so as to capture the knowledge acquisition, assimilation, and transformation (e.g., absorptive capacity), through the development of an interorganizational culture that cultivates the interorganizational integrative process mechanism (e.g., interactions and collaborations between the supplier and the customer), as discussed by Selnes and Sallis (2003) and Malhotra et al. (2005).

In addition, prior studies have extended absorptive capacity to the interorganizational context, and discuss the impact of absorptive capacity between exchange partners on interorganizational learning (e.g., Lane \& Lubatkin, 1998). Although the absorptive capacity perspective stresses the necessity of overlaps in the knowledge bases of exchange parties so that they may engage in interfirm learning, this argument is developed in the context of single-loop learning (Lane, Koka, \& Pathak, 2006). As a result, according to this view, absorptive learning is characterized as a learning race. In contrast, in our study relationship learning, a form of reciprocal and double-loop learning, emphasizes the reciprocal nature of the learning process as an effective knowledge integration mechanism that helps develop new knowledge through colearning and joint discovery. This helps relationship learning to overcome the limitation of dissimilar knowledge bases and enhance relationship-specific absorptive capacity through the development of mutual understanding and joint sense-making between two parties (Lubatkin, Florin, \& Lane, 2001). In sum, relationship learning depends not only on the similarity of the partners' general knowledge bases, but also on differences in the partners' knowledge domains (Grant \& Baden-Fuller, 2004). As pointed out by Lubatkin et al. (2001, p. 1367), "reciprocal learning requires no such information domain constraints, and indeed are better served when the overlap in knowledge is minimal."

The conceptual framework of the study also includes systems collaboration, as a technological driver of innovation. Systems collaboration is defined as the extent to which supply chain partners strive to make their supply chain 
systems compatible with each other and therefore ready for interfirm forecasting, planning, and collaborative product development (Kim \& Lee, 2010). The extant literature shows that advanced IT systems, used in a supply chain context, can facilitate interorganizational learning processes and ultimately lead to new market knowledge (Malhotra et al., 2005). Thus, systems collaborations can be viewed as interorganizational knowledge exchange processes, carried out through virtual interactions between exchange parties, via supply chain systems. Accordingly, it is logical to incorporate systems collaboration as a technological driver of innovation in our model.

Technological uncertainty is adopted in the model as an environmental variable. Environmental uncertainty has been identified in the literature as a driver of firms' innovative behaviors (e.g., Koufteros, Vonderembse, \& Jayaram, 2005). However, the unique technological environments of each industry could potentially have different impacts on firms' ability to innovate. For instance, in the context of the high-tech industry, technological uncertainty, manifested as the extent of unpredictable changes in the technological environment, which may quickly render existing technology obsolete, can drive a firm to develop better innovation capabilities in its exchange relationships in order to stay ahead of the competition. In addition, an uncertain and turbulent technological environment tends to create an abundance of technological knowledge, helping to develop innovative firm offerings (Sullivan \& Marvel, 2011).

In terms of innovation-performance relationships, the literature offers conflicting results. While some studies show that innovation generation is beneficial for firm performance (e.g., Han, Kim, \& Srivastava, 1998), others find no relationship or even a negative impact on financial performance (Hauser, Tellis, \& Griffin, 2006). In an effort to provide more concrete empirical insights into this debate, this study relies on the KBV (Grant, 1996a, 1996b) and links innovation generation in customer-supplier relationships to relationship performance. The $\mathrm{KBV}$ argues that knowledge is the most strategically important resource that firms possess. Furthermore, according to the KBV, innovation generation is the outcome of knowledge integration, application, and reconfiguration (Grant, 1996a), which can drive sustainable competitive advantage and eventually lead to better firm performance.

In addition, dependence, or power as its flip side, has been argued to play a central role in supply chain management (Tangpong, Michalisin, \& Melcher, 2008; Zhao et al., 2008). According to the RDT (Pfeffer \& Salancik, 1978), dependence refers to the degree to which a firm relies on its counterpart for access to scarce resources (Pfeffer \& Salancik, 1978). Those who control critical resources have power. Research suggests that power-dependence structures in exchange relationships can affect firms' innovative activities (Tangpong et al., 2008). However, empirical evidence on this issue is still limited. Given the importance of powerdependence in the supply chain, the current study, as shown in Figure S1, examines the moderating effects of supplier dependence on the relationships between the key drivers and performance outcomes of innovation generation in customer-supplier relationships.

Network theory argues about how the interdependence of actors and their positions in networks influence their opportunities, constraints, and behaviors 
(Granovetter, 1973; Zaheer \& Bell, 2005), offering a good theoretical basis for our study in terms of understanding the impact of power-dependence on firms' strategic behaviors. Prior studies have applied network theory in innovation and new product development research in the context of intra- and interfirm relationships (e.g., Ahuja \& Lampert, 2001; Rindfleisch \& Moorman, 2001; Wuyts, Stremersch, \& Dutta, 2004). According to such studies, a firm's network position can influence whether or not a unit accesses new knowledge that is critical for developing new products or innovative ideas (Tsai, 2001). Furthermore, a firm occupying a better position in a network has more power and is more likely to access desired strategic resources, such as information and knowledge. Consequently, we expect that the links between the drivers of innovation, innovation itself, and the resulting performance will be shaped by the extent of a supplier's dependence on its customer-supplier relationships.

Supporting this view, the RDT highlights the importance of control over critical resources within the organization (Pfeffer \& Salancik, 1978). That is, a less dependent supplier has more power to control and appropriate knowledge, as a critical resource, from its exchange partners, and thus to enhance its resource base in its exchange relationships. A supplier can leverage the power-dependence relationship to facilitate the flow and distribution of knowledge between its exchange partners, stimulating and supporting innovative activities (Davis \& Golicic, 2010).

\section{Influence of Supplier Market Knowledge Acquisition on Supplier Innovation Generation}

According to Zhou and Li (2012), supplier market knowledge acquisition refers to a supplier's strategy for acquiring information about customers' expressed and latent needs, and competitors' product and service offerings and market strategies. The supplier's market knowledge acquisition provides a focus for its product development and sales growth efforts by enabling it to develop strong relationships with key customers and gain insights into opportunities for market development. The market orientation literature views customer and competitor orientation as critical elements of organizational culture and as strategic orientations for supporting firm innovation (e.g., Gatignon \& Xuereb, 1997; Han et al., 1998). A customer-oriented firm that monitors its customers' needs closely tends to improve its creativity by producing novel and meaningful new products and processes that, in turn, enhance its innovation potential through its entire business system. In addition, a competitor-oriented firm tends to continually monitor its progress against that of other key firms, which can lead to opportunities to create products or processes that are differentiated from those of its competitors. Thus, it tends to facilitate innovations in order to stay abreast of its competitors. Supporting this view, Song and Thieme (2009) show that a supplier's involvement in market intelligence gathering can facilitate radical and incremental innovation.

The KBV also suggests that market knowledge pertaining to customers and competitors plays a crucial role in developing better product innovation (Sullivan \& Marvel, 2011). Zhou and Li (2012) indicate that knowledge acquisition is a knowledge integration mechanism that can enhance the width of suppliers' knowledge bases. Market knowledge acquisition helps expand the scope of information 
search beyond existing customers or markets. In addition, market information acquisition helps enhance knowledge identification through explorative learning (Cohen \& Levinthal, 1990). The infusion of new information from external sources likely generates new ideas for innovations. This is particularly true for suppliers with limited and narrow knowledge bases. Such suppliers have to rely on external sources in order to generate innovations. Hence,

H1: In customer-supplier relationships, a supplier's market knowledge acquisition is positively related to its innovation generation.

\section{Influence of Relationship Learning on a Supplier's Innovation Generation}

Following Selnes and Sallis (2003, p. 85), we define relationship learning as "a joint activity between a supplier and a customer in which the two parties share information, which is then jointly interpreted and integrated into a shared relationship-domain specific memory that changes the range or likelihood of potential relationship-domain-specific behavior." According to this view a typical organizational learning process may include multiple facets, such as the exchange of information, joint sense-making, and knowledge integration (Cheung et al., 2010). The literature shows that interorganizational learning enhances innovation by increasing the willingness to explore new ideas and develop new products and processes. Exposure to different knowledge and perspectives enhances the inclination to consider different alternatives, and thus increases creativity.

Exchange of information between the customer and the supplier in the buyersupplier relationship enables the parties to coordinate their plans and discuss operational and strategic issues as a part of interorganizational learning. This involves firms making an effort to go beyond the exchange of day-to-day operational information by sharing long-term information such as market trends, changes in customer preferences, new product introductions and future product plans. In sum, information exchange as a part of relationship learning in a customer-supplier relationship enables the firms to increase their knowledge base and, in turn, create new knowledge to facilitate innovation (Malhotra et al., 2005).

Joint sense-making between the customer and the supplier is also expected to enable a firm's innovative capability. When both parties jointly interpret information through cross-firm teams and frequent meetings, this can enable the firms to come to a more efficient consensus and avoid confusion and conflict in the exchange relationship. Only by joint sense-making can firms filter the information they receive from their exchange partners and transform it into their own firm's way of doing business, thus enabling innovation to take place. Moreover, frequent joint sense-making is expected to establish knowledge-sharing routines and thus facilitate the interaction between buyer and seller, further enhancing the propensity to innovate in the relationship (Roy et al., 2004; Wang et al., 2008).

As outlined above, according to the KBV absorptive capacity refers to an organization's ability to add new knowledge to existing knowledge (Grant, 1996b, p. 111) and such capacity involves organizational routines and processes that organizations use to acquire, assimilate, transform, and exploit knowledge to produce organizational capabilities (Malhotra et al., 2005). In our study, this KBV 
definition is included implicitly. It is suggested that relationship learning affects the level of organizational innovation to the extent to which both the supplier and customer have absorptive capacity. That is, relational learning is conceptualized to capture the knowledge acquisition, assimilation, and transformation through the development of an interorganizational culture that cultivates interorganizational mechanisms such as interactions and collaborations between the supplier and customer (Selnes \& Sallis, 2003; Malhotra et al., 2005).

The absorptive capacity perspective, developed in the context of absorptive and single-loop learning (Lane et al., 2006), suggests the necessity of the overlap of knowledge bases between exchange parties wishing to engage in interfirm learning. Rather than highlighting the learning-race, we focus on relationship learning, a form of reciprocal and double-loop learning that highlights the reciprocal nature of the learning process and is an effective knowledge integration mechanism that can help to develop new knowledge through colearning and joint discovery. Hence, relationship learning can overcome the limitation of dissimilar knowledge bases and enhance relationship-specific absorptive capacity through developing mutual understanding and joint sense-making between two parties (Lubatkin et al., 2001). Relationship learning depends not only on the similarity of the partners' general knowledge bases, but also on differences in the partners' knowledge domains (Grant \& Baden-Fuller, 2004).

The concept of relationship learning is supported by the knowledge accessing theory (Grant \& Baden-Fuller, 2004), which is grounded in the KBV. Knowledge accessing theory focuses on knowledge application, a form of knowledge sharing in which each member firm accesses its partner's stock of knowledge in order to exploit any complementarities. Thus, a supplier engaged in relationship learning is expected to generate new combinations from the existing knowledge, leading to better product and process innovations.

Based on these arguments, we propose:

H2: In customer-supplier relationships, relationship learning is positively related to supplier innovation generation.

\section{Influence of Systems Collaboration on Supplier Innovation Generation}

The systems collaboration dimension in this study is defined as the extent to which customers and suppliers strive to make and keep their supply chain systems compatible with each other. As Kim and Lee (2010) suggest, this compatibility allows partners to collaborate in forecasting, planning, and new product development. It has been argued that systems collaboration can eliminate potential integration barriers between exchange parties, which can arise from incompatibilities in supply chain communication technology (Frohlich, 2002). The integration of supply chain systems can facilitate interaction and coordination between customers and suppliers, increasing the likelihood that they will exchange ideas and opportunities (Kim \& Lee, 2010). According to the absorptive capacity perspective, the innovation outcome is a function of a firm's absorptive capacity to identify, assimilate, and exploit knowledge from the environment (Zahra \& George, 2002). Malhotra et al. (2005) assert that absorptive capacity can be enhanced through 
"common language" (p. 111) between partners and its efficient use through advanced communication tools such as information technology. Hence, systems collaboration can facilitate absorptive capacity related to knowledge acquisition, dissemination, and exploitation, which in turn leverage knowledge bases and enhance suppliers' innovation outcomes (Malhotra et al., 2005).

The literature also shows an association between IT systems, learning, and innovation. For instance, in the context of new product development, Ettlie and Paul (2006) find that IT can enable rapid, accurate, and reliable knowledge sharing and can increase the accessibility and availability of new knowledge for innovation. Further, Roy et al. (2004) imply that systems collaboration could facilitate the generation of innovation in the supply chain because any previously redundant knowledge can be captured through advanced IT systems that electronically link routine buyer-seller information, such as that related to production, forecasting, and planning. Supporting this view, our preliminary interviews showed that HTC, a Taiwanese mobile phone producer, has adopted advanced IT systems, such as product-design-manage systems, in order to link with foreign customers in its innovation process. The application of such systems has enabled organizations to reduce learning barriers and improve their product and process innovations. Thus, we predict:

\section{H3: In customer-supplier relationships, systems collaboration is positively related to supplier innovation generation.}

\section{Influence of Technological Uncertainty on Supplier Innovation Generation}

Technological uncertainty in this study is defined as the extent to which volatility, change, and unpredictability of technology exist in a supplier's cross-border customer-supplier relationships with its international customers (Lee, Chen, Kim, \& Johnson, 2008). The importance of the organization's innovation environment is generally well acknowledged in the literature (Souder, Sherman, \& Davies-Cooper, 1998). Building on this, the current study argues that suppliers adopt more innovative actions in order to adapt to, and take advantage of, opportunities that emerge from technological uncertainty in supplier-customer relationships. Unpredictable changes in the technological environment quickly render existing technology obsolete which is targeted at a certain customer, resulting in a shorter product life cycle. To minimize the threat of obsolescence, firms must introduce innovations that depart from their existing products, services, and markets. Firms that pursue such innovations can capitalize on changing circumstances by creating new products and services or meeting the needs of emerging markets (Jansen, Van Den Bosch, \& Volberda, 2006). For example, during our preliminary interviews with HTC, which manufactures Smartphones, a senior manager stated "in the Smartphone industry, technological uncertainty is quite significant, and we have to cultivate emerging technology trends like cloud computing and keep developing innovative products and services in order stay ahead of the competition."

Further, according to the KBV, firms are more likely to acquire technological knowledge to respond to changing markets via rapid product developments (Sullivan \& Marvel, 2011). The acquisition of such knowledge can enhance the 
firms' absorptive capabilities and compress their learning curves, while avoiding the need to expend scarce internal knowledge resources (Autry, Grawe, Daugherty, \& Richey, 2010). Some empirical evidence shows that a turbulent environment makes technological firms adopt more innovative strategies, implying that technological uncertainty leads to more innovation (Li \& Atuahene-Gima, 2001), even in the context of supplier-customer relationships. Hence, we make the following prediction:

H4: In customer-supplier relationships, technological uncertainty is positively related to supplier innovation generation.

\section{Impact of Supplier Innovation Generation on Relationship Performance}

Relationship performance in our study refers to the perceived economic performance of jointly acting parties in exchange relationships, relative to expectations and competitors' performance, in terms of measures such as sales growth, market share, and profitability (Sinkovics, Jean, Roath, \& Cavusgil, 2011). A supplier that generates more innovation should have the ability to create a relationship with its customer that contributes to its market and financial performance. It should be able to provide better product quality or deliver better products and services in a timely manner, which should enhance the effectiveness and efficiency of the exchange relationship. It should also gain more business opportunities to work with international customers, because its innovations will build its reputation. This, in turn, will enhance its sales or profits. For example, HTC, which is known for its innovation through the new generation of smartphones, has been able to build relationships with a variety of international customers as a result of its enhanced market and financial performance.

In line with this argument, the KBV suggests that innovation generation is an outcome of knowledge integration, application, and reconfiguration (Grant, 1996a) and can lead to sustainable competitive advantage and, eventually, better firm performance.

\section{H5: In customer-supplier relationships, supplier innovation generation is pos- itively related to relationship performance.}

\section{Moderating Effect of Supplier Dependence on the Innovation Generation Process}

The literature explores how the power-dependence structure influences a firm's innovation generation. However, little empirical work has been done to examine how power-dependence shapes the links between the drivers of innovation and innovation itself, and between innovation and firm performance. In order to fill this research gap, we explore the moderating effect of supplier dependence on the innovation generation process and its outcomes. According to the RDT (Pfeffer \& Salancik, 1978), an organization can be viewed as dependent on another if the latter controls an important resource or if there are no alternatives to that resource. Furthermore, when a party is dependent on another party, the latter has more power and controls more resources (Pfeffer \& Salancik, 1978). 
Network theory links power-dependence with network position and argues that network centrality can be regarded as an additional source of interorganizational power, over and above an actor's ability to generate dependencies through resource exchange (Astley \& Sachdeva, 1984). An actor in a more central network position is expected to control more resources. Complementing both the RDT and network theory, we argue that asymmetric dependence in the exchange relationship leads to asymmetry in the network structure between the actors involved. A dependent supplier lacking control of desired strategic resources is likely to occupy a less central network position. In contrast, a less dependent supplier is more likely to generate greater network centrality in its exchange relationship network, which leads to the control of critical resources.

The literature indicates that network centrality can facilitate information exchange and generation (Burt, 1997; Tsai, 2001). When a supplier is less dependent on the customer, the supplier has more autonomy and more opportunities to work with other customers. This enables it to gain access to different views about the market from different customers, which in turn provides it with a higher quality and quantity of information. In addition, a less dependent supplier is more likely to occupy a central network position, helping it to gain access to intelligence from diverse and multiple customers and competitors. That is, its network serves as an information-processing or screening mechanism (Ahuja, 2000). The strong-weak ties theory also argues for the brokering effect of less dependence and working with more customers (Hargadon \& Sutton, 1997; Hansen, 1999), which helps firms to gain more diverse information, which can help them in the development of new products and processes. In contrast, a more dependent supplier will be in a weaker network position and thus will lack the information advantage gained through gathering broad and diverse customer and competitor information. Thus, we expect that the degree of supplier dependence could moderate the influence of market knowledge acquisition on supplier innovation generation. A less dependent supplier is more likely to utilize the generated market knowledge in a way that supports its product and process innovation. This is consistent with the RDT, which suggests that a less dependent party can leverage its power to gain access to information or knowledge resources.

Similarly, a power-dependence structure characterized by a low degree of supplier dependence is expected to influence relationship learning processes. The literature shows that network position affects learning (Gulati, 1999). A less dependent supplier is likely to work with a broader scope of customers, which will help it to gather redeployable knowledge-knowledge gleaned from one customer that can be used to enhance the supplier's performance with other customers (Nobeoka, Dyer, \& Madhok, 2002). This redeployable knowledge can facilitate the knowledge transfer and integration process, and reduce learning costs. In addition, the presence of different sets of customers leads to a lower level of knowledge redundancy and is thus more likely to facilitate learning. In contrast, a highly dependent supplier must focus on dealing with its dominant customers and thus loses opportunities to gain novel ideas from diverse customer pools (Yli-Renko \& Janakiraman, 2008). In addition, relationships with a greater degree of asymmetry of dependence can induce more opportunistic behaviors, reducing joint learning while increasing learning costs, as argued by the RDT. That is, the more dependent party will try 
to engage in absorptive learning so as to gain knowledge from the dominant party and reduce its power asymmetry. In contrast, in less asymmetric exchange relationships, where suppliers are less dependent on their customers, partners are more willing to participate in joint learning activities to generate new combinations of existing knowledge. Accordingly, we predict that the effect of relationship learning on innovation generation is stronger under low supplier dependence.

Prior work also links systems collaboration with power-dependence structures (Seggie, Kim, \& Cavusgil, 2006). A dependent party is more likely to integrate its information systems with those of a dominant party in order to adapt to its needs and demands. Research shows that dependent suppliers will try to leverage systems collaboration as a strategic resource to enhance their bargaining power (Byrd \& Turner, 2001). However, there are some drawbacks to systems collaboration: it requires the commitment of a lot of resources, including IT infrastructures and human skills. Also, sharing too much critical information through systems collaborations with less important customers may incur the risk of the appropriation of sensitive knowledge. Thus, a less dependent supplier will wish to keep its autonomy and freedom, and will be less likely to accrue benefits in terms of innovation through systems collaboration with its key customer.

In terms of the moderating effect of supplier dependence on the link between technological uncertainty and supplier innovation generation in exchange relationships, we expect suppliers to generate more innovative outputs when they are less dependent on their customers, even in markets in which technology changes rapidly. The literature shows that the effect of technological uncertainty on innovation can be shaped by a firm's network position and dependence structure (Lee, 2010). Unpredictable changes in the technological environment can increase uncertainty and make the firm's existing technology obsolete. In order to keep up with frequently changing technology trends, a firm has to collect a wide scope of knowledge. Thus, we expect that a less dependent supplier will be able to occupy a more central network position and gather diverse technological information and knowledge to help it identify new product concepts and technology developments emerging from a turbulent technological environment. The RDT argues that a dependent party lacks control over critical resources such as the technological knowledge emerging from an uncertain technological environment (Pfeffer \& Salancik, 1978). In contrast, a less dependent party is more likely to leverage its power to manipulate the flow of knowledge and appropriate innovative outputs in an uncertain environment.

We sum up the hypotheses regarding the moderating effects of supplier dependence on the relationships between the drivers and outcomes of innovation generation, in the context of the customer-supplier relationship, as follows:

H6a: In customer-supplier relationships, the positive relationship between supplier market knowledge acquisition and supplier innovation generation is stronger when supplier dependence is low.

H6b: In customer-supplier relationships, the positive relationship between relationship learning and supplier innovation generation is stronger when supplier dependence is low. 
H6c: In customer-supplier relationships, the positive relationship between systems collaboration and supplier innovation generation is stronger when supplier dependence is high.

H6d: In customer-supplier relationships, the positive relationship between technological uncertainty and supplier innovation generation is stronger when supplier dependence is low.

\section{Moderating Effect of Supplier Dependence on the Link between Innovation and Relationship Performance}

The impact of dependence on innovation and performance has been discussed previously (e.g., Tsai, 2001; Lee, 2010). A supplier who is less dependent on a given customer can gain more resources from other customers and access the supplier knowledge or practices of those customers. Such a central network position may enhance its profitability and sales by allowing it to apply other customers' knowledge or practices to its products and processes in order to meet market needs, respond to emerging market trends, or deal with competitive challenges. In addition, less dependent suppliers have more power and autonomy to pursue innovative activities by creating new products and processes to meet the needs of emerging markets and consumers. As a result, they may be able to create opportunities for above-normal returns by targeting premium market segments and creating new niches (Jansen et al., 2006). Thus,

H7: In customer-supplier relationships, the positive relationship between supplier innovation generation and relationship performance is stronger when supplier dependence is low.

\section{Control Variables}

In the literature, a firm's organizational innovativeness has been associated with its innovation generation and performance (Azadegan, Dooley, Carter, \& Carter, 2008; Azadegan \& Dooley, 2010). Thus, a supplier's organizational innovativeness, defined as the extent to which it is inclined to engage in innovative behavior, such as adopting new ideas or processes (Deshpandé, Farley, \& Webster Jr., 1993; Hurley \& Hult, 1998), is included in our model as a control variable. Firm size and length of relationship, common control variables of firm performance, are also included. Firm size is a well-recognized factor in a firm's strategic moves and performance (Aiken \& West, 1991). Larger firms could, ceteris paribus, derive greater synergies from various resources, helping them to perform better in the markets or to implement different strategies (Aiken \& West, 1991; Wooldridge, 2000). The length of the relationship is viewed as a factor that results in stable interfirm relationships, cultivating an environment in which better relationship performance can be expected (Ganesan, 1994; Ryu, Park, \& Min, 2007). 


\section{METHOD}

\section{Unit of Analysis}

We chose to examine the specific cross-border relationships between Taiwanese suppliers and their international OEMs because Taiwanese suppliers tend to be smaller than their international OEM customers, and thus their relationships usually show power asymmetry. Furthermore, the Taiwanese electronics industry offers a valuable empirical context because its industry members have served as pioneers in information technology development, have championed cross-border relationships with U.S. and European industry leaders, and are actively participating in the world economy (Dedrick, Kraemer, Linden, Brown, \& Murtha, 2007). Taiwanese suppliers compete fiercely for contracts and cross-border exchange relationships with leading multinational enterprises (MNEs), such as IBM, HP, and Dell. Subcontracted activities include product development, manufacturing, and advanced product innovation and design (Quinn, 2000). For MNEs, this move toward outsourcing traditional upstream value chain activities is significant as it promises performance benefits and advantages over competitors. Hence, the disintegration of international supply chains is an important strategic feature in this market.

\section{Sampling Frame and Data Collection}

Senior account and marketing managers directly involved in international OEM relationships with branded firms were chosen as the key informants for this study. A survey methodology was used to collect the data. The sampling frame consisted of all electronic companies from the 2007 directory of the Top 5000 Largest Firms in Taiwan, published by China Credit Information Service Ltd (1,069 companies). All firms in the database were contacted to assess their eligibility and to locate appropriate informants for the study. Respondents were asked to specify their most important international OEM customers in terms of the largest sales volume. We considered this to be critical to our investigation of the asymmetric nature of crossborder relationships. In our sample, approximately three-quarters of the suppliers' sales were derived from their single most important OEM customer.

Data collection was conducted in two stages. First, in-depth interviews were conducted with 15 senior account and marketing managers or directors of Taiwanese suppliers. This initial qualitative and exploratory approach provided valuable inputs for the refinement of the questionnaire and the adaptation of the key constructs to the industry context. The interviews in fact served as an a priori test of the key constructs with respect to their usefulness and appropriateness. Second, the final survey instrument was mailed out to Taiwanese electronics companies from the directory. Yu and Cooper's (1983) suggestions for maximizing response rates were applied and multiple contact points, via telephone and personal contacts, were established to solicit responses to the study. Questionnaires were also sent via e-mail to accommodate respondents' preferences for this format. For the telephone and participation requests via e-mail, each informant who agreed to participate in the study was faxed or e-mailed a questionnaire packet. 


\section{Survey Response and Informant Evaluation}

A total of 246 useable questionnaires were returned, resulting in an effective response rate of $23.01 \%(246 / 1,069)$. Table S1 shows the respondent characteristics. The international OEM customers in the dataset are from the USA, Japan, Germany, China, and France. The Taiwanese electronics suppliers in the sample are involved in the supply of computer components, semiconductors, communication products, computer peripherals, and optoelectronics. Over $67 \%$ of the Taiwanese suppliers are small to medium-sized (i.e., with less than 250 employees). The survey instrument used made it possible for us to identify the level of each supplier's dependence on its main international OEM customer, both in terms of resource endowment and the potential to replace it with another customer.

We assessed nonresponse bias by classifying the responses into two groups, early respondents (the first quartile) and late respondents (the last quartile) (Armstrong \& Overton, 1977). Independent $t$-tests were performed on demographic variables such as revenue and employee numbers. No significant differences were identified for these descriptive variables between the early and late respondents to our mail survey. $T$-tests were also run between these two groups on key variables in the proposed conceptual model, such as technological uncertainty, supplier innovativeness, innovation generation, and relationship performance. Again, no significant differences emerged.

A reliable assessment of nonresponse bias can only be achieved via feedback from the nonrespondents themselves. Therefore, we identified a selection of nonrespondents and called them to obtain explanations for their lack of response. In all cases, the reasons provided to us regarding the lack of response were related to time pressures in filling out the questionnaire, the general notion that the questionnaire was too demanding and the fact that other requests for feedback had to be prioritized. These findings imply that nonresponse bias does not pose a significant threat to the study.

\section{Measurement Scales}

Multi-item scales and a seven-point response format were used to operationalize all constructs and variables in the study. The measures were adapted from existing studies and refined based on feedback from experienced researchers and practitioners in the area of inquiry.

The supplier market knowledge acquisition scales were adapted from Slater and Narver (2000) to measure the extent to which the organizational culture focuses on acquiring knowledge about customers' expressed and latent needs, and competitors' capabilities and strategies. For relationship learning, we measured the joint activities between exchange partners, through which they share information and jointly interpret it in order to generate mutual behavior (Selnes \& Sallis, 2003; Cheung et al., 2010; Jean, Sinkovics, \& Kim, 2010b). The scales for relationship learning were borrowed from Jean et al. (2010b) and adapted for the current study.

Systems collaboration was conceptualized as the extent to which the supplier's and customer's information systems are integrated with each other so as to be ready for potential interfirm collaborative activities, such as planning, demand forecasting, and new product development. We measured systems collaboration 
using three items adapted from Kim and Lee (2010). Technological uncertainty was conceptualized to capture product complexity, technological innovation, and the rate of technological change in the industry (Celly, Spekman, \& Kamauff, 1999). It was adapted from Celly et al.'s (1999) and Jaworski and Kohli's (1993) technological turbulence scales. Supplier innovation generation was operationalized as the supplier's application or utilization of knowledge, measured as the outcome in terms of modifications and/or innovative improvements to products or processes (Nielsen \& Nielsen, 2009). Supplier dependence was measured as the supplier's perception of the extent to which it depends on its key customer. The scale was taken from Lusch and James (1996) and adapted for this study. For relationship performance, we adopted Selnes and Sallis' (2003) conceptualization, namely the effectiveness and efficiency of business relationships between suppliers and customers. Finally, to measure the control variables, we adapted the scale developed by Hurley and Hult (1998) for supplier's organizational innovativeness, and developed a single item for the length of the relationship.

\section{Measurement Model Results}

To evaluate the measurement model, we conducted confirmatory factor analysis (CFA) using EQS for Windows 6.1. In the CFA, we specified all constructs as reflective. In specifying measures for constructs, the literature suggests that no clear causality, interchangeable and covarying measures, or shared antecedents and consequences should be used to determine whether or not a construct is reflective (Petter, Straub, \& Rai, 2007, pp. 633-634). A careful examination revealed that some constructs, including relationship learning, have measures that may potentially exhibit a level of causality from the measures to the latent construct. However, those measures also suggest that they are interchangeable and covarying, and share the same antecedents and consequences. Therefore, in our case all the measures seem to meet the conditions for reflective scales. Furthermore, the current state of the literature reveals that specifying measures as reflective offers operational advantages, including the use of CFA and advanced statistical software in the data analysis process. Particularly, considering that this study is directed toward theory testing, we specified our constructs as reflective, following suggestions in the literature (Diamantopoulos \& Siguaw, 2006; Hair, Ringle, \& Sarstedt, 2011).

The CFA model includes all eight study constructs. In the measurement purification process, items with an unacceptable loading (i.e., less than 0.5) were eliminated to increase convergent validity (Bagozzi \& Yi, 1988; Bollen, 1989). For discriminant validity, item scales linked to more than one construct were removed as well. After this process, at least three items remained for each construct. The final CFA model shows a good fit of the measurement model with the covariances provided by the dataset: $\chi^{2}=458.711$ on 271 d.f., NNFI $=0.939, \mathrm{CFI}=0.949$, and RMSEA $=0.053$ (Bentler \& Chou, 1987; Hu \& Bentler, 1999).

Subsequently, we assessed the validity of each construct by evaluating their unidimensionality, convergent and discriminant validity, and reliability for internal consistency (Fornell \& Larcker, 1981). First, for unidimensionality, we examined the largest standardized residual reported. This was 0.18 , indicating that there is 
no significant threat to the unidimensionality of the constructs (Fornell \& Larcker, 1981). Moreover, all items are significantly loaded on their corresponding factors $(p<.01)$ and their loadings are all greater than 0.5 , as shown in Table 1 . These loadings indicate an adequate level of convergent validity (Nunnally \& Bernstein, 1994). For good discriminant validity, average variance extracted (AVE) should be greater than the shared variances of each construct (Fornell \& Larcker, 1981). As shown in Table S2, the AVEs range from 0.58 to 0.73 , and the shared variances among the constructs range from 0.00 to 0.56 , as reported in the upper triangle of the table. These results demonstrate a good level of discriminant validity among our study's constructs (Bagozzi \& Yi, 1988; Dyer \& Singh, 1998). Finally, the composite reliability of each construct is calculated using the formula suggested in the literature (Fornell \& Larcker, 1981); these values are reported in Table 1. All composite reliabilities are greater than 0.80, above the acceptable level of 0.7 discussed in the literature (Nunnally \& Bernstein, 1994).

\section{Common Method Bias Assessment}

When a survey method is used to collect data from a single source, common method bias is always a potential threat. To assess the extent to which common method bias affects our results, we pursued a rigorous approach using hierarchically nested covariance structure models (e.g., Cote \& Buckley, 1987). We estimated three models: a trait-only model (M2), a method-only model (M3), and a trait-andmethod model (M4). According to the results, variances from the construct items (or traits) exist but those from the method are only weakly present $(p>.01)$, as is shown in Table S3. Subsequently, to assess the extent to which such method variances are present, we calculated the mean percentages of variance explained by the construct items and by the common method factor. The results show that the mean percentage of variance explained by the construct items is $59.5 \%$, while that of the common method factor is only $7.3 \%$, indicating that common method bias is minor. Therefore, we conclude that common method bias does not pose a major threat to the study.

\section{ANALYSIS AND RESULTS}

To test our hypotheses, the proposed structural model with all measurement items from the CFA model was estimated using EQS 6.1 for Windows. According to the results, the proposed structural model fits very well with the empirical covariances from the data, with $\chi^{2}=477.54$ on 260 d.f., $\mathrm{NNFI}=0.927, \mathrm{CFI}=$ 0.937 , and RMSEA $=0.058$, as reported in Figure 1 . Based on the good fit of the structural model, the proposed hypotheses are tested. In H1, we maintained that a supplier's market knowledge acquisition positively affects its innovation generation. According to the results, this is supported, with $\mathrm{b}=0.248(p<.01)$. In $\mathrm{H} 2$, we proposed that a supplier's relationship learning enhances its innovation generation. The results lend support to this hypothesis, with $b=0.160$ ( $p<$ .05). Regarding a supplier's systems collaboration with its international buyer, we suggested in $\mathrm{H} 3$ that such collaboration results in improvements in the supplier's innovation generation, which the results support, with $\mathrm{b}=0.156(p<.05)$. H4 
Table 1: Measures and composite reliabilities.

Construct (Composite Reliability: $\mathrm{CR} \eta$ ), Item (Loading)

Market knowledge acquisition $(\mathrm{CR} \eta=\mathbf{0 . 8 9})(1=$ strongly disagree $; 7=$ strongly agree)

In your relationship with the key international customer

We use multiple methods to gather information about our main international customer's products, services, and strategies. (0.82)

We frequently collect information about our main international customer's operations that is relevant to our business (e.g., purchasing, marketing, R\&D). (0.95)

We continually review the likely effects of changes in the business environment that may affect our international customer management practices. (0.81)

We regularly collect information about our competitors' products, services, and strategies. (0.67)

We regularly analyze information about our competitors. ${ }^{a}$

We regularly monitor information about our competitors' products, services, and strategies. $^{\mathrm{a}}$

Relationship Learning $(\mathrm{CR} \eta=\mathbf{0 . 8 9})(1=$ strongly disagree $; 7=$ strongly agree $)$

In your relationship with the key international customer

It is common to establish joint teams to solve operational problems in the relationship. $(0.70)$

It is common to establish joint teams to analyze and discuss strategic issues. (0.92)

The atmosphere in the relationship stimulates productive discussion encompassing a variety of opinions. (0.93)

Systems Collaboration $(\mathrm{CR} \eta=\mathbf{0 . 8 4})(1=$ strongly disagree; $7=$ strongly agree $)$

In your relationship with the key international customer

Relying on our information system, we collaborate on forecasting and planning with our international customer. (0.96)

Collaboration in demand forecasting and planning with our international customer is always possible through our information system. (0.88)

We use the Internet and our information system in conjunction with our international customer to create our new business opportunities. (0.51)

Technological Uncertainty $(\mathrm{CR} \eta=\mathbf{0 . 8 7})(1=$ strongly disagree $; 7=$ strongly agree $)$

Please indicate your agreement with each of the following statements with respect to your firm's environment

The technology in our industry is changing rapidly. (0.68)

Technological changes provide big opportunities in our industry. (0.73)

There is a high level of technological innovation in our industry. (0.90)

More complex products are provided in our industry. (0.85)

Supplier Innovation Generation $(\mathrm{CR} \eta=\mathbf{0 . 8 9})(1=$ strongly disagree $; 7=$ strongly agree)

Please think of the benefits in your relationship with the key international customer

Creation of new products, product enhancements. (0.74)

Enhance product quality. (0.91)

Improvements to current processes or creation of new processes. (0.89)

Relationship Performance $(\mathrm{CR} \eta=\mathbf{0 . 8 9})(1=$ strongly disagree $;$ Please think of the benefits in your relationship with the key international customer Our relationship with our customer helps to increase sales growth. (0.88)

Our relationship with our customer helps to increase our market share. (0.80)

Our relationship with our customer helps to increase our profitability. (0.71) 
Table 1: Continued

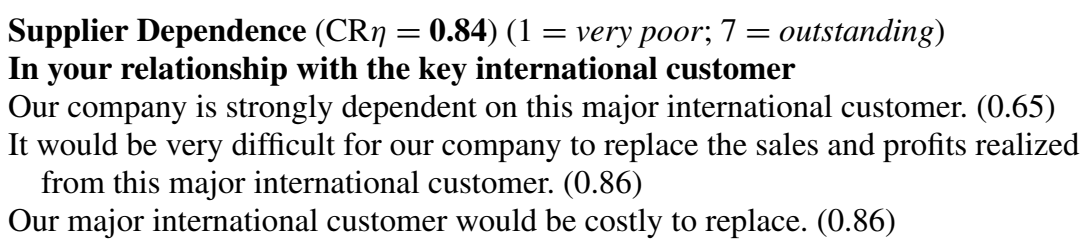

Organizational Innovativeness $(\mathrm{CR} \eta=\mathbf{0 . 8 7})(1=$ strongly disagree; $7=$ strongly agree)

Please answer the following with respect to your firm's innovativeness.

Our firm's management actively seeks innovative ideas. (0.88)

Innovative ideas are readily accepted in program/project management. (0.90)

Technologically innovative thoughts are always welcomed in our company. (0.69)

Measurement model fit indices: Chi-Square $=458.711$ on 271 d.f.

$\mathrm{NNFI}=0.939$

$\mathrm{CFI}=0.949$

RMSEA $=0.053$

${ }^{a}$ Item deleted after scale purification process.

states that technological uncertainty has a positive impact on supplier innovation generation, which is supported by the results, with $\mathrm{b}=0.201(p<.01)$. H5 proposes that supplier innovation generation positively influences relationship performance. The results provide support for this, with $b=0.750(p<.01)$.

In terms of the moderating effects, we expected that high supplier dependence would decrease the effects of supplier market knowledge acquisition, relationship learning, and technological uncertainty on supplier innovation generation, as stated in Hypotheses 6a, 6b, and 6d, but increase the effect of systems collaboration (H6c). In addition, we expected that high supplier dependence would decrease the impact of supplier innovation generation on relationship performance (H7). To test these moderating effects, we carried out a multi-group analysis by median-splitting the sample according to supplier dependence (Bollen, 1989; Bentler, 2005; Johnsen \& Ford, 2008). Then the two-group analysis was carried out with equal constraints on all eight paths. However, the literature suggests that measurement invariance should be assessed when multiple groups are involved in the statistical analyses (Steenkamp \& Baumgartner, 1998). Furthermore, the literature requires both configural invariance and partial metric invariance to be supported in order for a comparison of standardized path coefficients to be made across groups, as in our study (Steenkamp \& Baumgartner, 1998). Therefore, the study followed Steenkamp and Baumgartner's (1998) procedure for carrying out measurement invariance tests. According to the results, configural invariance is supported, as the combination of significantly loaded items is consistent across the two groups (Steenkamp \& Baumgartner, 1998). In addition, metric invariance was assessed. According to the chi-squared difference test, two of the measurement items are not invariant $(p<.01)$ between the groups, one item each of relationship learning and innovation generation, indicating partial metric invariance for those constructs. Because 
Figure 1: Results of model estimation.

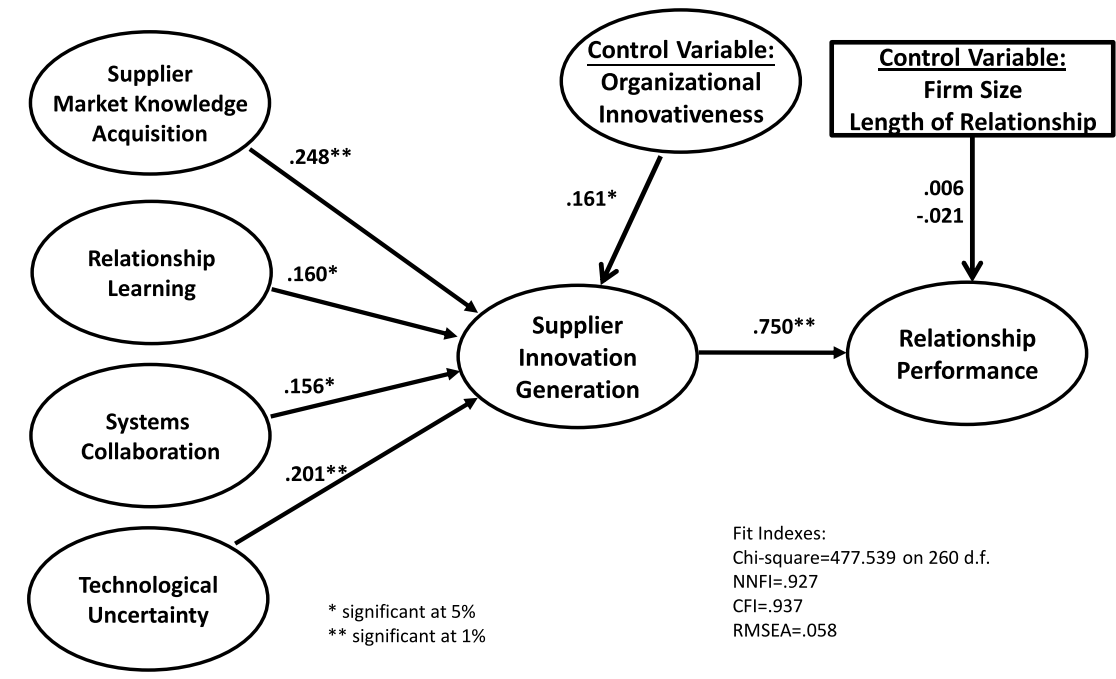

Figure 2: Results of two-group analysis.

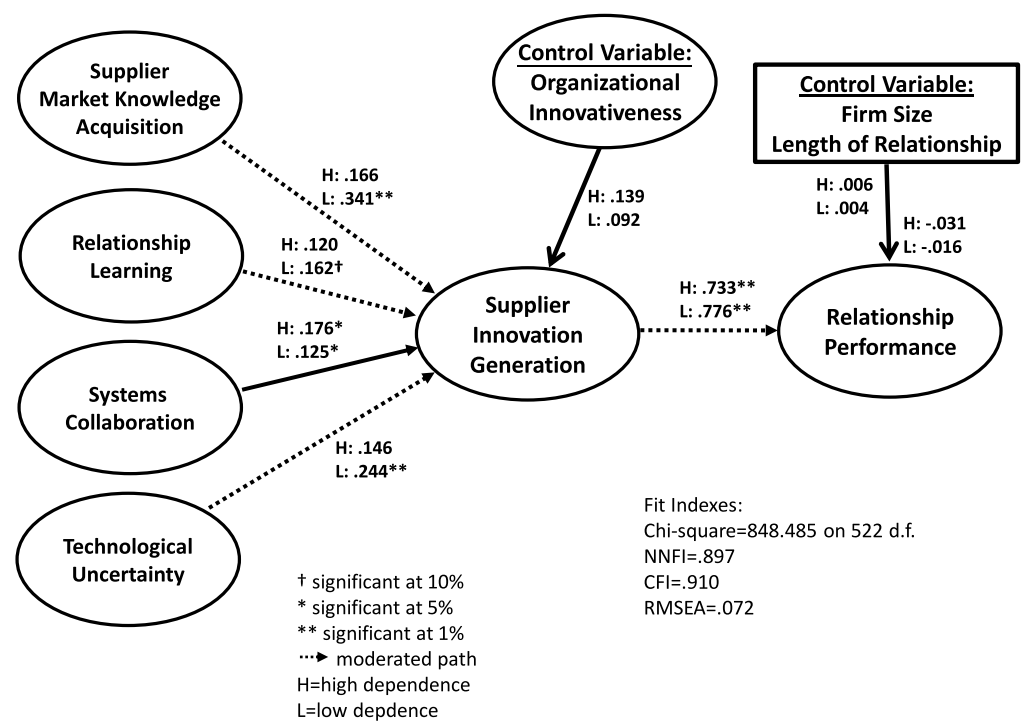

partial metric invariance is a sufficient condition for a two-group comparison to be made (Steenkamp \& Baumgartner, 1998), we proceeded with the multi-group analysis (Figure 2).

We estimated a two-group model with eight equal constraints- the five hypothesized paths and three control variables. We added an equal constraint on all control variables as well, because there is no theoretical reason why they should 
be different between the two groups. The chi-squared difference test of the multigroup analysis suggested that four of the paths were significantly different for the two groups. Thus, the constraints on those four paths were released and the model was estimated again. The results showed that there were no significantly different paths according to the chi-squared difference test. Furthermore, the final results reveal a good model fit, with $\chi^{2}=848.49$ on 522 d.f., NNFI $=0.897, \mathrm{CFI}=$ 0.910 , and RMSEA $=0.072$. Furthermore, the chi-squared difference tests show that supplier dependence moderates the impacts of supplier market knowledge acquisition $(\Delta \chi=8.66, p<.01)$, relationship learning $(\Delta \chi=6.03, p<.05)$, and technological uncertainty $(\Delta \chi=5.39, p<.05)$ on supplier innovation generation. However, the impact of systems collaboration on supplier innovation generation is not moderated by supplier dependence $(\Delta \chi=1.73, p>.05)$. Finally, the effect of supplier innovation generation on relationship performance is moderated by supplier dependence ( $\Delta \chi=4.16, p<.05)$. Therefore, H6a, H6b, H6d, and H7 are supported by the results but H6c is not.

\section{DISCUSSION}

With the increase in global innovation outsourcing and a significant shift toward supplier-driven innovation networks and open innovation, suppliers are now playing key roles in innovation generation in global supply chains. Research on innovation in supply chains is burgeoning (Roy et al., 2004; Sivakumar, Roy, Zhu, \& Hanvanich, 2010), yet our understanding of the antecedents and consequences of innovation generation in supply chains remains rather unclear. Moreover, empirical research that explores the moderating effect of power-dependence on the effects of the drivers and outcomes of innovation in supply chain contexts is rather sparse. Our objective is to explore how suppliers can enhance the innovation generation in their customer-supplier relationships with international OEM customers, and the influence of such innovation generation on the relationship performance. In addition, we explore how supplier dependence moderates such effects. Drawing on the KBV and learning theory, we develop and empirically test an integrative model that delineates the antecedents and performance outcomes of supplier innovation generation in customer-supplier relationships. Further, this study applies network position and RDT to examine the moderating effects of supplier dependence on the links between drivers and innovation and between innovation and performance. This study broadens and deepens our understanding of how innovation by suppliers can be generated in customer-supplier relationships and how it increases the competitiveness of these suppliers. Next, we discuss our results.

\section{Drivers of Innovation Generation}

Following the KBV and organizational learning literature, this study identifies technological, organizational, and environmental drivers of innovation generation by suppliers in customer-supplier relationships. We include supplier market knowledge acquisition and relationship learning as organizational context drivers. Systems collaboration is included in the model as a technological context driver. Technological uncertainty is incorporated as an environmental variable. The 
results show that supplier market knowledge acquisition has the strongest effect on supplier innovation generation, followed by systems collaboration, technological uncertainty and relationship learning. Consistent with prior work, which highlights the importance of market knowledge capabilities in facilitating firm innovativeness (Li \& Calantone, 1998; Jay, 2003), this finding suggests that market learning, in terms of the generation of information about both customers and competitors, is crucial in helping the supplier create new knowledge about new products and processes.

The findings also demonstrate that relationship learning can foster innovation generation in customer-supplier relationships. We provide empirical evidence of the link between interorganizational learning and innovation-an important, but underexplored issue in the literature (Easterby-Smith, Lyles, \& Tsang, 2008). Relationship learning has been associated with different performance outcomes in the literature, such as market performance and relationship value (Cheung et al., 2010; Jean et al., 2010b). However, our results extend our understanding of these links by relating relationship learning to innovation outcomes such as product and process innovations. In addition, recent studies have highlighted the importance of research that simultaneously examines both absorptive and joint learning capabilities in collaborative ventures (Medlin, 2006). Our findings make substantial contributions to this stream of research by demonstrating how market knowledge acquisition (absorptive learning) and relationship learning (joint learning) can contribute to innovation in exchange relationships.

The results further demonstrate that systems collaboration can contribute to supplier innovation generation. While prior work has indicated the importance of interorganizational systems to organizational learning and innovation (Scott, 2000; Roy et al., 2004), empirical evidence of this is still sparse. Our findings show that when supply chain systems are compatible with each other and enable interfirm collaborative activities they can foster knowledge sharing, which facilitates the achievement of beneficial innovation outcomes in customer-supplier relationships. This is consistent with Malhotra et al. (2005) and Ettlie and Pavlou's (2006) recent arguments and findings about the critical role played by IT in the supply chain, in facilitating the creation of new knowledge and the generation of innovation.

Our results further demonstrate that technological uncertainty may actually enhance supplier innovation and that an unpredictable and changing technological environment provides an ideal learning platform through which firms can identify emerging market opportunities and discover niche market segments. This finding is in line with the results of earlier organizational innovation research, which suggested that environmental uncertainties shape innovation (Damanpour, 1991; Frambach \& Schillewaert, 2002). These results confirm the importance and value of supplier-driven innovation in the presence of frequent technological changes and updates in an industry.

\section{Outcomes of Innovation Generation}

Our results show that supplier innovativeness can enhance relationship performance. This finding sheds light on the interrelationships between the innovation 
and performance of the two parties in an exchange relationship. Supplier innovation, following the logic of the $\mathrm{KBV}$, is regarded as a critical organizational resource and capability, which can drive firm value in interfirm relationships. Our finding provides empirical evidence of the link between innovation and performance in the context of interfirm relationships, an important but underexplored stream of research (Calantone, Cavusgil, \& Zhao, 2002). The results suggest that a creative firm can meet the changing needs of its customers by generating highly innovative and superior products and processes, which in turn will enhance its relationship performance.

\section{Role of Supplier Dependence}

Power-dependence structures play an important role in managing supply chain relationships and can shape firms' control of the strategic resources needed to generate innovative activities. Despite the presumed impact of power-dependence on innovation generation and performance in the customer-supplier relationship (Tangpong et al., 2008), the literature does not pay a great deal of research attention to these links. Our findings demonstrate the moderating role of supplier dependence on both the links between drivers and innovation and those between innovation and performance within the exchange relationship. As the literature argues, the nature of social relationships and dependence structures plays an important role in the organizational innovation-performance link. For example, in the context of organizational units, Tsai (2009) examines the impact of network centrality on firm innovation and performance. Our study extends this research to the interorganizational and supply chain context, offering substantial support for his arguments.

The results show that the degree of supplier dependence affects the supplier's power in terms of controlling critical resources in its exchange relationships, and thus influences its network position. A supplier with a lower level of dependence on its customer can occupy a more central network position and this facilitates relationship learning. This strengthens the positive effect of market information generation and relationship learning on innovation generation. Prior studies have indicated that a firm's structure can influence innovation within the firm. For example, Brockman and Morgan (2003) argue that a less formalized and centralized organization can acquire knowledge more easily. This study extends their work to the interorganizational level and suggests that a less dependent structure can also offer learning opportunities and ultimately, innovations.

However, we do not find a significant moderating effect of supplier dependence on the impact of systems collaboration on innovation generation. One plausible reason for this may be that the IT-enabled exchange of ideas and opportunities is more codified and structured and, therefore, less likely to be influenced by the power-dependence structure in the customer-supplier relationship. This result is consistent with Kim et al.'s (2006) recent finding that firms generally try to deploy systems collaboration and integration with all of their channel partners, rather than only with dependent partners.

Regarding the moderating effect of supplier dependence on the link between technological uncertainty and supplier innovation generation, our results indicate 
that technological uncertainty can drive greater supplier innovation when there is less supplier dependence. The learning environment provided by technological unpredictability can have a greater effect in power-dependence structures. The results support network theory, which suggests that firms can be motivated to obtain more diverse information and resources for innovation generation through less dependent structures and tend to hold stronger network positions under higher environmental turbulence (Hansen, 1999; McEvily \& Zaheer, 1999).

Although prior studies have examined the innovation-performance link in different contexts, the empirical results have been mixed (Hult, Hurley, \& Knight, 2004; Vincent et al., 2004). The current research finds that supplier dependence has a negative effect on the link between organizational innovation and performance in supply chain relationships. Hence, our empirical findings make a substantial contribution to the literature by revealing the importance of considering contingent effects such as power-dependence structures on the innovation-performance link (Rosenbusch, Brinckmann, \& Bausch, 2011).

\section{Contributions of the Study}

This study makes some unique contributions. First, it is rare to find studies in the literature that provide an overarching theory of innovation. Our work draws on different theoretical lenses and offers an integrative model to answer the questions of how suppliers can generate innovation in customer-supplier relationships, and what are the ultimate performance implications of such innovation. Second, the focus of the majority of innovation research has been either the relationship between innovation and its antecedents or between innovation and associated performance outcomes. Very few studies have attempted to model the entire relationship while focusing on the role of innovation as a mediator and discussing its drivers and outcomes simultaneously, particularly in the supply chain context. This study empirically tests a model and supports the role of innovation as a mechanism through which different types of drivers can create a competitive advantage for a firm in the supply chain. Finally, very few studies have examined the impact of the powerdependence structure as a moderator that shapes innovation generation processes and performance outcomes. Our study is distinctive in examining the moderating effect of supplier dependence on the links between drivers and innovation and innovation and performance in the supply chain context.

\section{Managerial Implications}

This research offers further insights to practitioners. In particular, our results show that innovation generation is a key driver for suppliers' success in their relationships with powerful industrial buyers. The innovative supplier can generate a competitive advantage and customer value through advanced and improved products and processes. This is the case particularly for suppliers who shift from traditional manufacturing roles to take more responsibility for innovative activities within the supply chain. An innovation strategy can help suppliers to deal with dominant buyers and stay ahead of the competition. 
With respect to the drivers of supplier innovation generation in customersupplier relationships, the results show that it can be affected by market knowledge acquisition, relationship learning, systems collaboration, and technological uncertainty. Thus, the managers of supplying firms who are trying to increase their innovative activities should assess these technological, organizational, and environmental aspects. Successful supplier innovation relies on appropriate organizational, technological, and environmental circumstances to create an effective and efficient learning environment.

Furthermore, managers need to realize that power-dependence structures can shape innovation generation and performance outcomes. A highly dependent and asymmetric relationship structure can create relationship stress, which can potentially impede a supplier's innovative ideas (Henke \& Zhang, 2010). A supplier with more autonomy and less dependence can occupy a central network position and access more diverse information and knowledge from its customers, which in turn facilitates innovation generation. In addition, a less dependent structure can help enhance the ultimate performance outcomes of supplier innovation. Our results may also have implications for managers working in firms that are dominant customers, who should pay more attention to creating a collaborative environment by reducing their exercise of power over their key customer and instead creating a trusting relationship, which will enable innovative activities to thrive within the exchange relationship.

\section{LIMITATIONS AND FURTHER RESEARCH}

Our results should be interpreted in light of several inherent limitations. First, supplier innovation was measured using subjective measurement and focused on product and process innovation only. Future studies should also include objective measures of supplier innovation, such as patents or R\&D expenditure. In addition, prior studies show that different conceptualizations may have different antecedents and outcomes. Hence, future research could examine other innovation types, such as incremental versus radical innovation, or technological versus administrative innovation, and identify their antecedents and performance outcomes in the supply chain. For example, Jansen et al. (2006) develop and test a model of antecedents, moderators, and performance outcomes of exploratory and exploitative innovation in the intra-organizational context.

Future studies could apply our theoretical framework in the context of exploratory and exploitative innovation in supply chains (Davis \& Golicic, 2010; Hsieh, Yeh, \& Chen, 2010). Although research on exploration versus exploitation in the organizational context is well developed in the literature (e.g., Benner \& Tushman, 2003; Liu, 2006; Gómez-Limón, Gómez-Ramos, \& Sanchez Fernandez, 2009), our understanding of how this plays out in the context of supply chain relationships and innovation generation is limited and therefore future research on the topic would be likely to contribute to the literature. In addition, we have only tested the moderating effects of power-dependence on the drivers and outcomes of innovation. Future research could explore other moderators such as the cultural differences between international exchange partners engaged in supply chain relationships (Rosenbusch et al., 2011). While we adopt social network theory and 
ascertain the network centrality in the exchange relationship, we only use the bimodal relationship as the unit of analysis. Future research could extend the level of analysis and use a more expanded social network to examine the impact of network ties on innovation generation in supply chains (Brian \& Ryon, 2003; Echols \& Tsai, 2005).

In terms of methodology, this study relies on data collected from Taiwanese OEM suppliers. Due to the limited scope of this sample, it is difficult to generalize our findings to other international customer-supplier relationships, especially in other industrial contexts. Future research should thus consider obtaining data from other industries, and from both customers and their suppliers, to cross-check the validity of the proposed model. This may prove very challenging, as the identity of customers is considered highly sensitive information in this type of international relationship. Yet overcoming these obstacles would provide a contribution to our thorough understanding of innovation generation in international supply chains. Furthermore, we adopted a single respondent strategy for our survey, which could potentially produce a common method bias. While we have carefully assessed such possible biases, future research should collect data using multiple respondents from each organization, so as to minimize common method bias.

Another limitation of this study is its cross-sectional design. Although our results reveal the drivers and performance outcomes of supplier innovation generation, their causality can only be implied. Future studies could overcome this limitation by using longitudinal data collection, even if it were only over relatively short periods.

In addition, we measure systems collaboration based on three items only. Because collaboration among supply chain partners at various information system levels requires individual systems to have flexible and compatible infrastructures, future studies could explore the multinational nature of systems collaboration, including IT infrastructure integration constructs such as cross-functional application integration (Rai, Patnayakuni, \& Seth, 2006) or IT flexibility (Byrd \& Turner, 2000, 2001). Further, the market knowledge acquisition construct in our study only includes one item to measure competitor information acquisition. Further work is warranted to advance the operationalization of this construct.

Finally, while the criteria used to determine whether the measures of a construct are reflective or formative are still under development in the literature (Petter et al., 2007), the measures of some constructs in our study, such as relationship learning and relationship performance, may deserve further investigation in future studies. Although we assessed their potential as formative constructs using the criteria offered in the literature (e.g., Petter et al., 2007), there is still some uncertainty as to whether their conceptualization is reflective or formative. Recognizing this, future studies are encouraged to investigate some of our study constructs as possible formative constructs, clarifying their theoretical and practical implications as formative versus reflective constructs.

\section{CONCLUSION}

As global competition intensifies, industrial buyers continue to develop new products more quickly and add sophisticated innovation through collaborations with 
external suppliers. This trend poses great challenges for the suppliers, who must enhance their innovative capabilities in an attempt to serve their international customers. Overall, this study provides a strong theoretical and empirical foundation for understanding how suppliers can augment their innovation capabilities by working with their customers in cross-border exchange relationships, and thus improve performance outcomes.

\section{Supporting Information}

Additional supporting information may be found in the online version of this article:

Table S1: Demographic characteristics of the respondent firms $(\mathrm{n}=246)$.

Table S2: Intercorrelations and shared variances of measures $(n=246)$.

Table S3: Assessment of common method bias.

Figure S1: Conceptual framework.

Please note: Wiley-Blackwell is not responsible for the content or functionality of any supporting materials supplied by the authors. Any queries (other than missing material) should be directed to the corresponding author for the article.

\section{REFERENCES}

Ahuja, G. (2000). Collaboration networks, structural holes, and innovation: A longitudinal study. Administrative Science Quarterly, 45(3), 425-455.

Ahuja, G., \& Lampert, C. M. (2001). Entrepreneurship in the large corporation: A longitudinal study of how established firms create breakthrough inventions. Strategic Management Journal, 22(6-7), 521-543.

Aiken, L., \& West, S. (1991). Multiple regression: Testing and interpreting interactions. Thousands Oaks, CA: Sage.

Armstrong, J. S., \& Overton, T. S. (1977). Estimating nonresponse bias in mail surveys. Journal of Marketing Research, 14(3), 396-402.

Astley, W. G., \& Sachdeva, P. S. (1984). Structural sources of intraorganizational power: A theoretical synthesis. The Academy of Management Review, 9(1), 104-113.

Autry, C. W., Grawe, S. J., Daugherty, P. J., \& Richey, R. G. (2010). The effects of technological turbulence and breadth on supply chain technology acceptance and adoption. Journal of Operations Management, 28(6), 522-536.

Azadegan, A., \& Dooley, K. J. (2010). Supplier innovativeness, organizational learning styles and manufacturer performance: An empirical assessment. Journal of Operations Management, 28(6), 488-505.

Azadegan, A., Dooley, K. J., Carter, P. L., \& Carter, J. R. (2008). Supplier innovativeness and the role of interorganizational learning in enhancing manufacturer capabilities. Journal of Supply Chain Management, 44(4), 14-35.

Bagozzi, R. P., \& Yi, Y. (1988). On the evaluation of structural equation models. Journal of the Academy of Marketing Science, 16(1), 74-94. 
Benner, M. J., \& Tushman, M. L. (2003). Exploitation, exploration, and process management: The productivity dilemma revisited. Academy of Management Review, 28(2), 238-256.

Bentler, P. M. (2005). EQS 6 structural equations program manual. Encino, CA: Multivariate Software.

Bentler, P. M., \& Chou, C.-P. (1987). Practical issues in structural modeling. Sociological Methods Research, 16(1), 78-117.

Bollen, K. A. (1989). Structural equations with latent variables. New York, NY: Wiley.

Brian, U., \& Ryon, L. (2003). Relational embeddedness and learning: The case of bank loan managers and their clients. Management Science, 49(4), 383-399.

Brockman, B. K., \& Morgan, R. M. (2003). The role of existing knowledge in new product innovativeness and performance. Decision Sciences, 34(2), 385-419.

Burt, R. S. (1997). The contingent value of social capital. Administrative Science Quarterly, 42(2), 339-365.

Byrd, T. A., \& Turner, D. E. (2000). Measuring the flexibility of information technology infrastructure: Exploratory analysis of a construct. Journal of Management Information Systems, 17(1), 167-208.

Byrd, T. A., \& Turner, D. E. (2001). An exploratory analysis of the value of the skills of IT personnel: Their relationship to infrastructure and competitive advantage. Decision Sciences, 32(1), 21-54.

Calantone, R. J., Cavusgil, S. T., \& Zhao, Y. (2002). Learning orientation, firm innovation capability, and firm performance. Industrial Marketing Management, 31(6), 515-524.

Celly, K. S., Spekman, R. E., \& Kamauff, J. W. (1999). Technological uncertainty, buyer preferences and supplier assurances: An examination of Pacific rim purchasing arrangements. Journal of International Business Studies, 30(2), 297-310.

Cheung, M.-S., Myers, M. B., \& Mentzer, J. T. (2010). Does relationship learning lead to relationship value? A cross-national supply chain investigation. Journal of Operations Management, 28(6), 472-487.

Cohen, W. M., \& Levinthal, D. A. (1990). Absorptive capacity: A new perspective on learning and innovation. Administrative Science Quarterly, 35(1), 128152 .

Cote, J. A., \& Buckley, M. R. (1987). Estimating trait, method, and error variance: Generalizing across 70 construct validation studies. Journal of Marketing Research, 24(3), 315-318.

Damanpour, F. (1991). Organizational innovation: A meta-analysis of effects of determinants and moderators. Academy of Management Journal, 34(3), 555 .

Davis, D. F., \& Golicic, S. L. (2010). Gaining comparative advantage in supply chain relationships: The mediating role of market-oriented IT competence. Journal of the Academy of Marketing Science, 38(1), 56-70. 
Davis, D. F., \& Golicic, S. L. (2010). Gaining comparative advantage in supply chain relationships: The mediating role of market-oriented IT competence. Journal of the Academy of Marketing Science, 38(1), 56-70.

Dedrick, J., Kraemer, K. L., Linden, G., Brown, C., \& Murtha, T. (2007). Organizing global knowledge networks in the electronics industry. Irvine, CA: Personal Computing Industry Center.

Deshpandé, R., Farley, J. U., \& Webster, F. E. Jr. (1993). Corporate culture customer orientation, and innovativeness in Japanese firms: A quadrad analysis. Journal of Marketing, 57(1), 23-37.

Diamantopoulos, A., \& Siguaw, J. A. (2006). Formative versus reflective indicators in organizational measure development: A comparison and empirical illustration. British Journal of Management, 17(4), 263-282.

Dyer, J. H., \& Singh, H. (1998). The relational view: Cooperative strategy and sources of inteorganizational competitive advantage. Academy of Management Review, 23(4), 660-679.

Easterby-Smith, M., Lyles, M. A., \& Tsang, E. W. K. (2008). Inter-organizational knowledge transfer: Current themes and future prospects. Journal of Management Studies, 45(4), 677-690.

Echols, A., \& Tsai, W. (2005). Niche and performance: The moderating role of network embeddedness. Strategic Management Journal, 26(3), 219-238.

Ettlie, J. E., \& Pavlou, P. A. (2006). Technology-based new product development partnerships. Decision Sciences, 37(2), 117-147.

Fornell, C., \& Larcker, D. F. (1981). Evaluating structural equation models with unobservable variables and measurement error. Journal of Marketing Research, 18(1), 39-50.

Frambach, R. T., \& Schillewaert, N. (2002). Organizational innovation adoption: A multi-level framework of determinants and opportunities for future research. Journal of Business Research, 55(2), 163-176.

Frohlich, M. T. (2002). E-integration in the supply chain: Barriers and performance. Decision Sciences, 33(4), 537-556.

Ganesan, S. (1994). Determinants of long-term orientation in buyer-seller relationships. Journal of Marketing, 58(2), 1-19.

Gatignon, H., \& Xuereb, J.-M. (1997). Strategic orientation of the firm and new product performance. Journal of Marketing Research, 34(1), 77-90.

Gómez-Limón, J. A., Gómez-Ramos, A., \& Sanchez Fernandez, G. (2009). Foresight analysis of agricultural sector at regional level. Futures, 41(5), 313-324.

Granovetter, M. S. (1973). The strength of weak ties. The American Journal of Sociology, 78(6), 1360-1380.

Grant, R. M. (1996a). Prospering in dynamically-competitive environments: Organizational capability as knowledge integration. Organization Science, 7(4), 375-387.

Grant, R. M. (1996b). Toward a knowledge-based theory of the firm. Strategic Management Journal, 17(Winter Special Issue), 109-122. 
Grant, R. M., \& Baden-Fuller, C. (2004). A knowledge assessing theory of strategic alliances. Journal of Management Studies, 41(1), 61-84.

Gulati, R. (1999). Network location and learning: The influence of network resources and firm capabilities on alliance formation. Strategic Management Journal, 20(5), 397-420.

Hair, J. F., Ringle, C. M., \& Sarstedt, M. (2011). PLS-sem: Indeed a silver bullet. Journal of Marketing Theory \& Practice, 19(2), 139-152.

Han, J. K., Kim, N., \& Srivastava, R. K. (1998). Market orientation and organizational performance: Is innovation a missing link? Journal of Marketing, 62(4), 30-45.

Hansen, M. T. (1999). The search-transfer problem: The role of weak ties in sharing knowledge across organization subunits. Administrative Science Quarterly, 44(1), 82-111.

Hargadon, A., \& Sutton, R. I. (1997). Technology brokering and innovation in a product development firm. Administrative Science Quarterly, 42(4), 716749.

Hauser, J., Tellis, G. J., \& Griffin, A. (2006). Research on innovation: A review and agenda for marketing science. Marketing Science, 25(6), 687-717.

Henke, J. W. J., \& Zhang, C. (2010). Increasing supplier-driven innovation. Sloan Management Review, 51(2), 41-46.

Hsieh, T.-J., Yeh, R.-S., \& Chen, Y.-J. (2010). Business group characteristics and affiliated firm innovation: The case of Taiwan. Industrial Marketing Management, 39(4), 560-570.

Hu, L.-t., \& Bentler, P. M. (1999). Cutoff criteria for fit indexes in covariance structure analysis: Conventional criteria versus new alternatives. Structural Equation Modeling: A Multidisciplinary Journal, 6(1), 1-55.

Hult, G. T. M., Hurley, R. F., Giunipero, L. C., \& Nichols, E. L. (2000). Organizational learning in global purchasing: A model and test of internal users and corporate buyers. Decision Sciences, 31(2), 293-325.

Hult, G. T. M., Hurley, R. F., \& Knight, G. A. (2004). Innovativeness: Its antecedents and impact on business performance. Industrial Marketing Management, 33(5), 429-438.

Hurley, R. F., \& Hult, G. T. M. (1998). Innovation, market orientation, and organizational learning: An integration and empirical examination. Journal of Marketing, 62(3), 42-54.

Jansen, J. J. P., Van Den Bosch, F. A. J., \& Volberda, H. W. (2006). Exploratory innovation, exploitative innovation, and performance: Effects of organizational antecedents and environmental moderators. Management Science, 52(11), 1661-1674.

Jaworski, B. J., \& Kohli, A. K. (1993). Market orientation: Antecedents and consequences. Journal of Marketing, 57(3), 53-70.

Jay, W. (2003). Exploring the role of market learning capability in competitive strategy. European Journal of Marketing, 37(3), 407-429. 
Jean, R.-J. B., \& Sinkovics, R. R. (2010). Relationship learning and performance enhancement via advanced information technology: The case of Taiwanese dragon electronics firms. International Marketing Review, 27(2), 200-222.

Jean, R.-J. B., Sinkovics, R. R., \& Cavusgil, S. T. (2010a). Enhancing international customer-supplier relationships through IT resources: A study of Taiwanese electronics suppliers. Journal of International Business Studies, 41(7), 12181239.

Jean, R.-J. B., Sinkovics, R. R., \& Kim, D. (2008). Information technology and organizational performance within international business to business relationships: A review and an integrated conceptual framework. International Marketing Review, 25(5), 563-583.

Jean, R.-J. B., Sinkovics, R. R., \& Kim, D. (2010b). Drivers and performance outcomes of relationship learning for suppliers in cross-border customersupplier relationships: The role of communication culture. Journal of International Marketing, 18(1), 63-85.

Johnsen, R. E., \& Ford, D. (2008). Exploring the concept of asymmetry: A typology for analysing customer-supplier relationships. Industrial Marketing Management, 37(4), 471-483.

Kim, D., Cavusgil, S. T., \& Calantone, R. J. (2006). Information system innovations and supply chain management: Channel relationships and firm performance. Journal of the Academy of Marketing Science, 34(1), 40-54.

Kim, D., \& Lee, R. P. (2010). Systems collaboration and strategic collaboration: Their impacts on supply chain responsiveness and market performance. Decision Sciences, 41(4), 955-981.

Koufteros, X., Vonderembse, M., \& Jayaram, J. (2005). Internal and external integration for product development: The contingency effects of uncertainty, equivocality, and platform strategy. Decision Sciences, 36(1), 97-133.

Lane, P. J., Koka, B. R., \& Pathak, S. (2006). The reification of absorptive capacity: A critical review and rejuvenation of the construct. Academy of Management Review, 31(4), 833-863.

Lane, P. J., \& Lubatkin, M. (1998). Relative absorptive capacity and interorganizational learning. Strategic Management Journal, 19(5), 461-477.

Lee, R. P. (2010). Extending the environment-strategy-performance framework: The roles of multinational corporation network strength, market responsiveness, and product innovation. Journal of International Marketing, 18(4), 58-73.

Lee, R. P., Chen, Q., Kim, D., \& Johnson, J. L. (2008). Knowledge transfer between multinational corporations' headquarters and their subsidiaries: Influences on and implications for new product outcomes. Journal of International Marketing, 16(2), 1-31.

Li, H., \& Atuahene-Gima, K. (2001). Product innovation strategy and the performance of new technology ventures in China. Academy of Management Journal, 44(6), 1123-1134. 
Li, T., \& Calantone, R. J. (1998). The impact of market knowledge competence on new product advantage: Conceptualization and empirical examination. Journal of Marketing, 62(4), 13-29.

Liu, W. (2006). Knowledge exploitation, knowledge exploration, and competency trap. Knowledge and Process Management, 13(3), 144-161.

Lubatkin, M., Florin, J., \& Lane, P. (2001). Learning together and apart: A model of reciprocal interfirm learning. Human Relations, 54(10), 1353-1382.

Lusch, R. F., \& Brown, J. R. (1996). Interdependency, contracting, and relational behavior in marketing channels. Journal of Marketing, 60(4), 19-38.

Malhotra, A., Gosain, S., \& Sawy, O. A. E. (2005). Absorptive capacity configurations in supply chains: Gearing for partner-enabled market knowledge creation. MIS Quarterly, 29(1), 145-187.

McEvily, B., \& Zaheer, A. (1999). Bridging ties: A source of firm heterogeneity in competitive capabilities. Strategic Management Journal, 20(12), 1133-1156.

Medlin, C. J. (2006). Self and collective interest in business relationships. Journal of Business Research, 59(7), 858-865.

Nielsen, B. B., \& Nielsen, S. (2009). Learning and innovation in international strategic alliances: An empirical test of the role of trust and tacitness. Journal of Management Studies, 46(6), 1031-1056.

Nobeoka, K., Dyer, J. H., \& Madhok, A. (2002). The influence of customer scope on supplier learning and performance in the Japanese automobile industry. Journal of International Business Studies, 33(4), 717-736.

Nunnally, J. C., \& Bernstein, I. H. (1994). Psychometric theory. New York, NY: McGraw-Hill.

Petter, S., Straub, D., \& Rai, A. (2007). Specifying formative constructs in information systems research. MIS Quarterly, 31(4), 623-656.

Pfeffer, J., \& Salancik, G. R. (1978). The external control of organizations : A resource dependence perspective. London, UK; New York, NY: Harper \& Row.

Powell, W. W., Koput, K. W., \& Smith-Doerr, L. (1996). Interorganizational collaboration and the locus of innovation: Networks of learning in biotechnology. Administrative Science Quarterly, 41(1), 116-145.

Provan, K. G., \& Gassenheimer, J. B. (1994). Supplier commitment in relational contract exchanges with buyers: A study of interorganizational dependence and exercised power. Journal of Management Studies, 31(1), 55-68.

Quinn, J. B. (2000). Outsourcing innovation: The new engine of growth. Sloan Management Review, 41(4), 13-28.

Rai, A., Patnayakuni, R., \& Seth, N. (2006). Firm performance impacts of digitally enabled supply chain integration capabilities. MIS Quarterly, 30(2), 225246.

Rindfleisch, A., \& Moorman, C. (2001). The acquisition and utilization of information in new product alliances: A strength-of-ties perspective. Journal of Marketing, 65(2), 1-18. 
Rosenbusch, N., Brinckmann, J., \& Bausch, A. (2011). Is innovation always beneficial? A meta-analysis of the relationship between innovation and performance in SMEs. Journal of Business Venturing, 26(4), 441-457.

Rowley, T. J. (1997). Moving beyond dyadic ties: A network theory of stakeholder influences. The Academy of Management Review, 22(4), 887-910.

Roy, S., Sivakumar, K., \& Wilkinson, I. F. (2004). Innovation generation in supply chain relationships: A conceptual model and research propositions. Journal of the Academy of Marketing Science, 32(1), 61-79.

Ryu, S., Park, J. E., \& Min, S. (2007). Factors of determining long-term orientation in interfirm relationships. Journal of Business Research, 60(12), 12251233.

Scott, J. E. (2000). Facilitating interorganizational learning with information technology. Journal of Management Information Systems, 17(2), 81-113.

Seggie, S. H., Kim, D., \& Cavusgil, S. T. (2006). Do supply chain IT alignment and supply chain interfirm system integration impact upon brand equity and firm performance? Journal of Business Research, 59(8), 887-895.

Selnes, F., \& Sallis, J. (2003). Promoting relationship learning. Journal of Marketing, 67(3), 80-95.

Sinkovics, R. R., Jean, R.-J., Roath, A. S., \& Cavusgil, S. T. (2011). Does IT integration really enhance supplier responsiveness in global supply chains? Management International Review, 51(2), 193-212.

Sivakumar, K., Roy, S., Zhu, J., \& Hanvanich, S. (2010). Global innovation generation and financial performance in business-to-business relationships: The case of cross-border alliances in the pharmaceutical industry. Journal of the Academy of Marketing Science, 39(5), 1-20.

Slater, S., \& Narver, J. (2000). Intelligence generation and superior customer value. Journal of the Academy of Marketing Science, 28(1), 120-127.

Song, M., \& Thieme, J. (2009). The role of suppliers in market intelligence gathering for radical and incremental innovation. Journal of Product Innovation Management, 26(1), 43-57.

Souder, W. E., Sherman, J. D., \& Davies-Cooper, R. (1998). Environmental uncertainty, organizational integration, and new product development effectiveness: A test of contingency theory. Journal of Product Innovation Management, 15(6), 520-533.

Steenkamp, J.-B., \& Baumgartner, H. (1998). Assessing measurement invariance in cross-national consumer research. Journal of Consumer Research, 25(1), 78-90.

Sullivan, D. M., \& Marvel, M. R. (2011). Knowledge acquisition, network reliance, and early-stage technology venture outcomes. Journal of Management Studies, 48(6), 1169-1193.

Tangpong, C., Michalisin, M. D., \& Melcher, A. J. (2008). Toward a typology of buyer-supplier relationships: A study of the computer industry. Decision Sciences, 39(3), 571-593. 
Tsai, K.-H. (2009). Collaborative networks and product innovation performance: Toward a contingency perspective. Research Policy, 38(5), 765-778.

Tsai, W. (2001). Knowledge transfer in intraorganizational networks: Effects of network position and absorptive capacity on business unit innovation and performance. Academy of Management Journal, 44(5), 996-1004.

Vincent, L. H., Bharadwaj, S. G., \& Challagalla, G. N. (2004). Does innovation mediate firm performance? A meta-analysis of determinants and consequences of organizational innovation. Working Paper, Georgia Institute of Technology, Atlanta, GA.

Wang, Q., Bradford, K., Xu, J., \& Weitz, B. (2008). Creativity in buyer-seller relationships: The role of governance. International Journal of Research in Marketing, 25(2), 109-118.

Wooldridge, J. M. (2000). Introductory econometrics: A modern approach. Cincinnati, OH: South-Western College Publishing.

Wuyts, S., Stremersch, S., \& Dutta, S. (2004). Portfolios of interfirm agreements in technology-intensive markets: Consequences for innovation and profitability. Journal of Marketing, 68(2), 88-100.

Yli-Renko, H., \& Janakiraman, R. (2008). How customer portfolio affects new product development in technology-based entrepreneurial firms. Journal of Marketing, 72(5), 131-148.

Yu, J., \& Cooper, H. (1983). A quantitative review of research design effects on response rates to questionnaires. Journal of Marketing Research, 20(1), $36-44$.

Zaheer, A., \& Bell, G. G. (2005). Benefiting from network position: Firm capabilities, structural holes, and performance. Strategic Management Journal, 26(9), 809-825.

Zahra, S. A., \& George, G. (2002). Absorptive capacity: A review, reconceptualization, and extension. The Academy of Management Review, 27(2), 185-203.

Zhao, X., Huo, B., Flynn, B. B., \& Yeung, J. H. Y. (2008). The impact of power and relationship commitment on the integration between manufacturers and customers in a supply chain. Journal of Operations Management, 26(3), 368-388.

Zhou, K. Z., \& Li, C. B. (2012). How knowledge affects radical innovation: Knowledge base, market knowledge acquisition, and internal knowledge sharing. Strategic Management Journal, 33(9), 1090-1102.

Ruey-Jer "Bryan" Jean is an assistant professor of international business at National Chengchi University, Taiwan. He received his $\mathrm{PhD}$ from Manchester Business School, UK and his MSc in international trade from National Dong-Hwa University, Taiwan. His teaching covers areas such as marketing, management, and international business strategy. He previously worked as a post-doctoral research fellow at the Manchester Business School CIBER and his research focuses on interorganizational relationship management, with particular focus on online and 
international contexts. His work has appeared in Journal of International Business Studies, Management International Review, Journal of International Marketing, International Business Review, Critical Perspectives of International Business, International Marketing Review, and Journal of Business Research. He was born in Taiwan and now lives in Taipei.

Daekwan Kim is an associate professor of marketing and international business in the College of Business at Florida State University. His research interests include the impact of IT on firm marketing strategies and activities, marketing/international marketing strategies, multinational brand management, customer equity, and franchise marketing. His research has been published in the Journal of International Business Studies, Journal of Academy of Marketing Science, Decision Sciences, Industrial Marketing Management, Journal of Business Research, Journal of International Marketing, International Marketing Review, and other journals.

Rudolf R. Sinkovics is a professor of international business at the Manchester Business School (MBS), University of Manchester, UK, and director of the MBS-CIBER (Centre for Comparative and International Business Research). He previously held a number of visiting scholar positions, including ones at Michigan State University, University of Oklahoma, and University of Otago at Dunedin, New Zealand. His research centers on interorganizational governance, the role of ICT, and research methods in international business. Recent work focuses on rising powers and drivers of economic change. He received his $\mathrm{PhD}$ from Vienna University of Economics and Business (WU-Wien), Austria. His work has been published in international business and international marketing journals such as Journal of International Business Studies, Management International Review, Journal of World Business, International Business Review, Journal of International Marketing, and International Marketing Review. Born in Austria, he now lives and works in Manchester, UK. 